\title{
Strengthening the Competitiveness of Indonesia's Loser Sector Products in RCEP Cooperation
}

\author{
Ragimun Abdullah \& Imran Rosjadi \\ Fiscal Policy Agency, Ministry of Finance of Indonesia, Jakarta, Indonesia \\ ragimun@gmail.com, imran.rosjadi@gmail.com
}

\begin{abstract}
The purpose of this study is to map some of Indonesia's loser sector products which are commodities that need to be strengthened in the RCEP cooperation forum. In this study, the Revealed Comparative Advantage (RCA) formula is used to analyze the competitiveness of Indonesian export products. The average RCA results between, 2015-2019 show that out of the five food and beverage product items, most of them have high competitiveness. Meanwhile, the average RCA of livestock products, light industry and heavy industrial products has low competitiveness. A strengthening strategy to increase product competitiveness in the RCEP market requires several steps. These steps include identifying market access in RCEP partner countries, improving product quality and specialization, coordinating between the Government and the private sector and continuing to encourage bureaucratic reform, harmonization of regulations to obtain Smart Regulations.
\end{abstract}

Keywords: Loser sector product, strengthening competitiveness, strategy.

\section{Introduction}

The current free trade has become a world phenomenon. Almost all countries are included in free trade blocs or establish bilateral relations to carry out free trade agreements. Free trade blocs are trade liberalization agreements formed by several countries. In principle, bilateral cooperation and relations as well as free trade blocs want to benefit from cooperation between the countries involved (Obradovic, 2016). FTA is a free trade agreement between a country and another country or region (Gao \& Shaffer, 2019). FTAs can be formed bilaterally, for example between the United States and Singapore, the United States with Chile, Japan and Singapore and others. Likewise, FTAs are formed regionally or in regional areas such as the ASEAN Free Trade Area (AFTA), North America Free Trade Area (NAFTA) and the European Union, including the formation of an economic partnership in the Asia Pacific region known as the Regional Comprehensive Economic Partnership (RCEP), whose members consists of newly industrialized countries in the Asia Pacific region (Fukunaga \& Isono, 2013). The opportunity for this region to become an area of mutual benefit is very large.

Because it will have a population of more than 3.4 billion people or 47.5 percent of all RCEP members (plus India). Member countries are expected to control a market share of 29.5 percent of world trade with a value of USD 17 trillion. In addition, controlling the world GDP by 33.5 percent and is expected to grow at an average of 6 percent per year, plus potential market access, especially from China, India, South Korea and Japan (Indonesia.go.id, 2020). Based on some of the results of previous research, it is recommended that Indonesia does not need to worry about its participation in the RCEP membership, due to the impact it will experience. In fact, if Indonesia does not participate in this forum, it will have a negative impact on Indonesia. This will result in the disconnection of the Regional Value Chain (RVC) network with other RCEP members (Dahar \& Oktaviani, 2014). To take advantage of the formation of RCEP optimally will face several problems. Based on predictions, the biggest impact of liberalization from RCEP for Indonesia is on the manufactured product group. Another worry is the flood of imported products from other countries, especially from China.

On the other hand, Indonesia's superior export products are required to continue to make efficiency in order to compete. Thus the benefits of RCEP are for exports of Indonesian products. In the end, it is necessary to strengthen the competitiveness of Indonesian products. To encourage and increase the efficiency of superior domestic products, fiscal incentives and disincentives are one of the instruments. In this regard, studies are needed to mitigate various strategies and policies to increase the competitiveness of several industrial sectors, especially the products of the loser sector, to be more competitive with other member countries. Loser sector products are products that during the last five years have a downward trend (slowdown) in 
exports. The same thing can be based on some previous research results. The results of the study (Rahman et al, 2017; Mutiara et al, 2020) recommend that Indonesia does not need to worry about membership in RCEP because of the impact it will experience. In fact, if Indonesia does not participate in this forum, it will have a negative influence.

One of these negative influences is the disconnection from the Global Value Chain (GVC) network of RCEP members. However, several other member countries will also experience the same thing, namely, there are superior products or winner sectors and products that have low competitiveness or loser sectors in the competition among RCEP members. Several products have the potential to benefit (winner sector) in the RCEP forum, including the agricultural sector, mining products (extraction), wood products, chemical products/rubber/plastic and electronic products. Meanwhile, the loser sector products include food and beverage products, livestock, light industry and heavy industrial product. This study aims to analyze several loser sector products, which are one of the sectors that need strengthening competitiveness in RCEP cooperation. In addition, this research is also expected to obtain policy recommendations related to strategies for strengthening the competitiveness of loser sector products in the RCEP collaboration.

\section{Research Method}

This research uses a descriptive exploratory approach. One of them is Revealed Comparative Advantage (RCA). RCA is a concept commonly used to measure comparative advantage, but indirectly it can also describe the strength of competitiveness so that strategies can be made to strengthen the competitiveness of these products (Erkan and Saricoban, 2014). This approach is used to analyze the comparative competitiveness of Indonesia's loser sector products to RCEP member countries. The RCA formula is as follows: (Tambunan, 2010)

$$
\begin{aligned}
& \text { RCA }=\frac{(X i a) /(\text { totalXa })}{(X i w) /(\text { totalXw) }} \\
& \text { Where: } \\
& \mathrm{X} \quad=\text { export or export value; } \\
& \mathrm{i} \quad=\text { type of commodity; } \\
& \mathrm{a} \quad=\text { country of origin; } \\
& \mathrm{w} \quad=\text { world. }
\end{aligned}
$$

When RCA $<1$ or close to 0 , it means that commodity competitiveness is weak, and if RCA $>1$ means strong competitiveness. The higher the RCA of a commodity, the tougher its competitiveness will be. The data and information used in this study are data from the Central Bureau of Statistics and UN Comtrade. Besides that, it takes several sources from journals, mass media and the results of the Focus Group Discussion (FGD).

\section{Literature Review}

To strengthen competition in the global world arena requires high competitiveness of various items and products of a country which are stated in the competitiveness index (Siudek \& Aldona, 2014; Xiao, 2015). Indonesia's competitiveness from year to year has increased and decreased. Based on the assessment of the International Institute for Management Development (IMD) World Competitiveness Ranking 2020, Indonesia's competitiveness ranking fell to position 40 out of 63 countries. This is down from the previous year (2019) which was ranked 32 (Media Indonesia, 2020). According to the research results (Ministry of Trade, 2015) concluded that the increase in Indonesian exports was driven by increased world demand, not by increased competitiveness. The results of the Revealed Comparative Advantage (RCA) and Constant Market Share Analysis (CMSA) which were carried out by sector found that mineral products and stone/glass were commodities that had decreased competitiveness.

Foodstuff is the sector with the best export performance. Although animal and animal products, vegetables, textiles and metals have increased their competitiveness, these products have decreased their market share in several countries such as the United States, including the European Union. Most of Indonesia's export 
products experienced a decline in exports due to the economic crisis or the pandemic. Based on the calculation of the diamond porter index, it is concluded that the priority products that can be developed are footwear, the basic chemical industry, furniture and electronics. According to several news sources, several business sectors are affected by the current pandemic conditions. Eight business sectors have the potential to become potential winners and vice versa. These potential winner products include textiles and textile products, pharmaceutical chemicals and medical devices, food and beverages, electronic products, telecommunications services, logistics services, agricultural products, and MSME products (Business Tempo, 2020).

On the other hand, in addition to these potential winner products, there are several products from the loser sector, including several items of food and beverage products, livestock products, light industry and heavy industrial products. These products are needed to strengthen competitiveness through various strategies and implementations to enter the market (access) in member countries of the RCEP cooperation forum. According to research results (Ulfah \& Felianty, 2017) show that the competitiveness of Indonesian products is currently still weak compared to most other RCEP member countries. Therefore, the Government of Indonesia must improve the competitiveness of its products so that they can compete and at the same time optimize their participation in RCEP membership. This study uses the Global Trade Analysis Project (GTAP) version 9 application to predict and analyze the impact on all RCEP members with 43 products. The simulation results show that the implementation of the RCEP agreement is expected to improve trade performance, GDP and welfare of most member countries, including Indonesia.

Meanwhile, according to (Moenardy, 2020), several strategies need to be carried out by the Government of Indonesia to deal with RCEP in the form of the concept of trade in goods and international cooperation, to achieve national prosperity, namely by formulating strategies that are internal and external. Internal strategies, among others, the Government must optimize cooperation with exporters. One of them is conducting labor training to improve quality products, creating superior products that can dominate the market, and protecting farmers regarding monopoly on seeds and medicines. External strategies include the Government having to negotiate with partner countries that are trade rivals with China so that there is no surge in products from China to Indonesia. Likewise, regulations must be made with multinational companies to use Indonesian workers when building their industry in Indonesia.

\section{Results and Discussion}

\section{RCA Product Loser Sector Indonesia at the RCEP Forum}

Food and Beverage: The competitiveness of food and beverage products for the RCEP market from 2015 to 2019 is relatively good. Of the five items of HS for food and beverage products, there are 4 that are very good, namely HS 2106, HS 0901, HS 8476 and HS 0902. These four items of food and beverage products have an RCA greater than 1 . This means that these products have very high competitiveness in the markets of RCEP member countries. One of them is HS 2106 in the form of food preparations, with an average of 1.51 which means that it has high competitiveness. While two more items, namely HS 8476 in the form of Automatic Goods - Vending Machines have an average RCA in the RCEP market of 6.99 from 2015 to 2019. Likewise, for HS 0901 in the form of Coffee, Whether or not roasted has an average RCA of 3, 86 and HS 0902 in the form of Tea, whether or not flavored has an average RCA of 3.37 .

Especially for coffee and tea commodities, these two commodities have not been further processed which have higher added value. As for market access for food and beverage goods, RCEP member countries, especially tea, are mostly exported to New Zealand, China, Australia, and ASEAN countries. Meanwhile, many coffee commodities are exported to South Korea, New Zealand, Japan, China, Australia and ASEAN countries. Two items that have a low RCA are HS 2206 in the form of Cider, Perry, Mead and other Fermented. This commodity still needs strengthening of competitiveness to enter the RCEP market. This strengthening is in the form of increased added value through increased derivative products and increased market access to RCEP member countries. Following are the RCAs for Indonesian food and beverage products in the RCEP market and the world. 
Table 1: RCA Food and Beverage

\begin{tabular}{|l|r|c|c|c|c|c|c|c|c|c|c|c|}
\hline \multirow{2}{*}{ Uraian } & \multicolumn{2}{|c|}{2015} & \multicolumn{2}{c|}{2016} & 2017 & 2018 & 2019 & \multicolumn{2}{|c|}{ Average } \\
\cline { 2 - 11 } & \multicolumn{1}{|c|}{$\mathrm{R}$} & $\mathrm{W}$ & $\mathrm{R}$ & $\mathrm{W}$ & $\mathrm{R}$ & $\mathrm{W}$ & $\mathrm{R}$ & $\mathrm{W}$ & $\mathrm{R}$ & $\mathrm{W}$ & $\mathrm{R}$ & $\mathrm{W}$ \\
\hline [2106] Food preparations, n.e.5. & 1.69 & 1.06 & 1.59 & 1.08 & 1.56 & 1.03 & 1.42 & 1.00 & 1.27 & 0.93 & 1.51 & 1.02 \\
\hline [2206] Cider, perry, mead and other fermented & 0.02 & 0.08 & 0.01 & 0.04 & 0.01 & 0.05 & 0.01 & 0.04 & 0.01 & 0.00 & 0.01 & 0.04 \\
\hline [8476] Automatic goods-vending machines, & 11.10 & 4.00 & 8.41 & 3.18 & 6.65 & 2.25 & 4.50 & 1.33 & 4.28 & 1.49 & 6.99 & 2.45 \\
[0901] Coffee, whether or not roasted or decaf & 5.40 & 4.24 & 3.40 & 3.69 & 3.99 & 3.75 & 3.20 & 2.80 & 3.30 & 3.27 & 3.86 & 3.55 \\
\hline [0902] Tea, whether or not flavoured & 4.21 & 2.05 & 3.71 & 1.84 & 3.34 & 1.70 & 3.24 & 1.66 & 2.35 & 1.61 & 3.37 & 1.77 \\
\hline
\end{tabular}

Source: UN Comtrade, 2020, processed, R = RCEP, $W=$ World

Animal Husbandry Products: Based on predictions, the export value of Indonesian livestock commodities continues to increase. Moreover, there is a change in the classification of commodities including livestock products based on the Harmonized System (HS) and the Standard International Trade Classification (SITC), the number of commodities that were originally classified as 8 will become 12 commodities. This increase indicates a new industrial growth in the livestock sub-sector so that processed livestock products emerge which are products that are absorbed in the international market, including the RCEP market. Export products that fall into the livestock product category are live livestock, meat, skins, bones and horns. In addition, it includes new commodities, namely feed ingredients, feed and veterinary medicines (Bappenas, 2012). Table 2 shows the RCA for the livestock sector and livestock products. Almost all RCA in the livestock sector is still relatively low or far from 1 . Meanwhile, of the $14 \mathrm{HS}$ numbers of goods, some have an RCA of more than 1. These HS include HS 0301 in the form of live fish, which has an average RCA of 1.58 for RCEP and 4.30 for ASEAN. This HS is in the form of fish, and the opportunity to enter the RCEP market is huge. ASEAN countries that absorb the most ornamental fish from Indonesia include Singapore, Malaysia and Thailand. Meanwhile, ornamental fish exports to RCEP countries other than ASEAN are Australia, China, and New Zealand.

Table 2: RCA for Animal Husbandry and Animal Products Sector

\begin{tabular}{|c|c|c|c|c|c|c|c|c|c|c|c|c|}
\hline \multirow{2}{*}{ Uraian } & \multicolumn{2}{|c|}{2015} & \multicolumn{2}{|c|}{2016} & \multicolumn{2}{|c|}{2017} & \multicolumn{2}{|c|}{2018} & \multicolumn{2}{|c|}{2019} & \multicolumn{2}{|c|}{ Average } \\
\hline & R & W & R & W & R & W & R & W & R & W & R & W \\
\hline [0203] Meat of swine, fresh, chilled or frozen & 0.00 & 0.00 & 0.00 & 0.00 & 0.00 & 0.00 & 0.00 & 0.00 & 0.00 & 0.00 & 0.00 & 0.00 \\
\hline 0204] Meat of sheep or goats, fresh, chilled or frozen & 0.00 & 0.00 & 0.00 & 0.00 & 0.00 & 0.00 & 0.00 & 0.00 & 0.00 & 0.00 & 0.00 & 0.0 \\
\hline [0205] Meat of horses, asses, mules or hinnies, fresh, chilled & 0.00 & 0.00 & 0.00 & 0.00 & 0.00 & 0.00 & 0.00 & 0.00 & 0.00 & 0.00 & 0.00 & 0.00 \\
\hline [0207] Birds' eggs, in shell, fresh, preserved or cooked & 0.00 & 0.00 & 0.00 & 0.00 & 0.00 & 0.00 & 0.00 & 0.00 & 0.00 & 0.00 & 0.00 & \\
\hline [0208] Birds' eggs, not in shell, and egg yolks, fresh, dried, coo & 1.30 & 2.99 & 0.61 & 2.56 & 0.65 & 2.06 & 0.52 & 1.87 & 0.13 & 2.17 & 0.52 & \\
\hline [0301] Live fish & 2.01 & 3.92 & 1.57 & 4.07 & 1.65 & 4.07 & 1.27 & 3.62 & 1.41 & 3.64 & 1.58 & \\
\hline [0302] Fish, fresh or chilled (excluding fish fillets and other fif & 5.79 & 1.16 & 3.24 & 0.75 & 2.54 & 0.59 & 2.00 & 0.53 & 2.41 & 0.67 & 3.50 & \\
\hline [0303] Frozen fish (excluding fish fillets and other fish meat) & 1.26 & 1.74 & 1.35 & 1.99 & 1.53 & 2.05 & 1.12 & 1.61 & 1.32 & 1.93 & 1.37 & \\
\hline [0304] Fish fillets and other fish meat, whether or not minced, & 1.84 & 2.18 & 1.94 & 2.14 & 1.62 & 1.95 & 1.83 & 2.17 & 1.74 & 2.35 & 1.79 & \\
\hline [0405] Butter, incl. dehydrated butter and ghee, and other fats & 0.01 & 0.01 & 0.01 & 0.01 & 0.07 & 0.02 & 0.10 & 0.04 & 0.12 & 0.04 & 0.06 & \\
\hline [0410] Turtles' eggs, birds' nests and other edible products of & 10.40 & 20.32 & 12.30 & 35.00 & 19.10 & 42.84 & 19.70 & 41.15 & 26.10 & 48.83 & 17.52 & 37.6 \\
\hline [1603] Extracts and juices of meat, fish or crustaceans, mollus & 0.33 & 0.20 & 0.41 & 0.30 & 0.37 & 0.24 & 0.42 & 0.29 & 0.73 & 0.49 & 0.45 & \\
\hline [1604] Prepared or preserved fish; caviar and caviar substitut & 2.07 & 2.71 & 1.92 & 2.60 & 2.33 & 2.78 & 2.76 & 2.89 & 2.82 & 3.16 & 2.38 & \\
\hline [2301] Flours, meals and pellets, of meat or meat offal, of fish & 0.06 & $\mid 0.12$ & 0.09 & 0.12 & 0.01 & 0.02 & 0.03 & 0.04 & 0.20 & 0.23 & 0.08 & \\
\hline
\end{tabular}

Source: UN Comtrade, 2020, processed, R = RCEP, $\mathrm{W}=$ World 
Apart from living fish, there are several export commodities of livestock that are quite good, the average RCA yield is for both the RCEP market and the ASEAN market. These commodities include HS 0302 Fish, fresh or chilled, which has an average RCA of 3.5 and in ASEAN 4.81. In addition, the HS 0303 Frozen fish (excluding fish fillets and other fish meat) has an average RCA of 1.37 and in the ASEAN market 1.56. HS 0304 Fish Fillets and Other fish meat has an average RCA in the RCEP market of 1.79 and ASEAN 1.34. What is very interesting in this sector are livestock products with HS 0410 Turtles eggs, bird's nests and other edible products of the animal. In HS this product has a very high average RCA, namely 17.52 and in ASEAN it is 4.51.

Importing countries for products from HS 0410 are dominated by China and some ASEAN countries. Furthermore, other products that have an RCA of more than 1 are products with HS 1604 Prepared or preserved fish, caviar and caviar substitutes. This product has an average RCA in the RCEP market of 2.38 in the world of 2.83 and in ASEAN of 2.91. Meanwhile, importing countries for this product include China, Japan, South Korea and Australia as well as ASEAN countries. Other products that have an RCA value less than 1, such as HS 0405 in the form of butter, HS 1603 Extract and juices meat and HS 2301 flours, meals and pellets have an RCA of less than 1 for the RCEP and ASEAN markets. These results prove that livestock products have a tendency not to enter the RCEP and ASEAN markets compared to unprocessed livestock products.

Light Industrial Products: Furthermore, 12 items HS, products of light industries, turned out to be products that were still difficult to enter the RCEP country market. Of the 12 items, only 3 HS items had an average RCA greater than 1 for the 2015 to 2019 period. The three HS items were HS 2618, HS 2619 and HS 7106. First, HS 2618 Granulated slag "slag sand" from the manufactures of iron or steel has an average RCA of 1.19. The export market for this product in Australia, which began in 2019. Some have entered the ASEAN market. Second, HS 2619 Slag dross, scaling and other waste from manufactured iron or steel (Slag dross, scaling and other waste made of iron or steel) has an RCA for RCEP countries of 1.92, for the world 1.57 and ASEAN 2, 70. RCEP countries include Japan and China. Third, HS 7106 in the form of silver, including silver plated with gold or platinum, has an RCA in the RCEP market of 1.06, 0.58 for the world and 2.22 in ASEAN. The only RCEP countries importing these goods are Australia and Japan.

Table 3: RCA for Light Industry Products

\begin{tabular}{|c|c|c|c|c|c|c|c|c|c|c|c|c|}
\hline \multirow{2}{*}{ Uraian } & \multicolumn{2}{|c|}{2015} & \multicolumn{2}{|c|}{2016} & \multicolumn{2}{|c|}{2017} & \multicolumn{2}{|c|}{2018} & \multicolumn{2}{|c|}{2019} & \multicolumn{2}{|c|}{ Average } \\
\hline & R & W & R & W & R & W & R & W & R & W & R & W \\
\hline [2303] Residues of starch manufacture and similar residues, beet-puld & 0.01 & 0.02 & 0.04 & 0.07 & 0.12 & 0.11 & 0.09 & 0.10 & 0.08 & 0.12 & 0.07 & 0.09 \\
\hline [2521] Limestone flux; limestone and other calcareous stone, of a kind] & 0.00 & 0.00 & 0.14 & 0.04 & 0.00 & 0.00 & 0.00 & 0.00 & 0.00 & 0.00 & 0.03 & 0.01 \\
\hline [2618] Granulated slag "slag sand" from the manufacture of iron or ste] & 0.00 & 0.10 & 0.00 & 0.11 & 0.00 & 0.79 & 0.32 & 0.79 & 5.64 & 2.19 & 1.19 & 0.80 \\
\hline [2619] Slag, dross, scalings and other waste from the manufacture of $\mathrm{i}$ & 2.30 & 3.11 & 1.05 & 1.48 & 0.99 & 0.88 & 2.88 & 0.96 & 2.37 & 1.40 & 1.92 & 1.57 \\
\hline [3804] Residual lyes from the manufacture of wood pulp, whether or $n$ ] & 0.01 & 0.01 & 0.01 & 0.01 & 0.02 & 0.01 & 0.00 & 0.00 & 0.01 & 0.01 & 0.01 & 0.01 \\
\hline [7106] Silver, incl. silver plated with gold or platinum, unwrought or if & 1.23 & 0.49 & 1.01 & 0.60 & 0.89 & 0.53 & 1.13 & 0.60 & 1.03 & 0.69 & 1.06 & 0.58 \\
\hline [8002] Tin waste and scrap (excluding ash and residues from the many] & 2.76 & 0.23 & 0.00 & 0.00 & 0.00 & 0.00 & 0.00 & 0.00 & 0.00 & 0.00 & 0.55 & 0.05 \\
\hline [8435] Presses, crushers and similar machinery used in the manufacty] & 0.11 & 0.04 & 0.55 & 0.17 & 0.17 & 0.04 & 0.18 & 0.04 & 0.02 & 0.01 & 0.21 & 0.06 \\
\hline [8449] Machinery for the manufacture or finishing of felt or nonwoven] & 0.00 & 0.01 & 0.00 & 0.01 & 0.00 & 0.00 & 0.00 & 0.00 & 0.05 & 0.04 & 0.01 & 0.01 \\
\hline [8477] Machinery for working rubber or plastics or for the manufactur & 0.05 & 0.05 & 0.04 & 0.05 & 0.04 & 0.04 & 0.05 & 0.05 & 0.05 & 0.05 & 0.05 & 0.05 \\
\hline [8486] Machines and apparatus of a kind used solely or principally fo] & 0.01 & 0.01 & 0.01 & 0.02 & 0.00 & 0.01 & 0.00 & 0.01 & 0.01 & 0.01 & 0.01 & 0.01 \\
\hline [8487] Machinery parts, n.e.s. in chapter 84 (excluding parts containif & 0.35 & 0.26 & 0.50 & 0.35 & 0.27 & 0.19 & 0.10 & 0.08 & 0.22 & 0.14 & 0.29 & 0.21 \\
\hline
\end{tabular}

Source: UN Comtrade, 2020, processed, R = RCEP, W = World

Heavy Industrial Products: Other Indonesian export products are heavy industrial products. Heavy equipment is a large machine designed to carry out construction work such as dredging work, moving building materials and others. Heavy equipment is an important factor in projects, especially construction and mining projects and other activities on a large scale. The heavy equipment industry plays an important role in supporting other business activities, such as in the mining sector, forest land management, 
infrastructure development, as well as plantations and agriculture. The results of the calculation of the average RCA for Indonesian heavy equipment industrial products to RCEP countries are still below 1, meaning that the competitiveness of Indonesian heavy equipment industrial products is still low and cannot compete with similar products from other countries. The production of Indonesia's heavy industry includes railroads, trains and their equipment, containers, tractors, the products of the automotive industry (motorbikes, cars), the products of the weaponry industry and others. Of the 21 selected heavy equipment industrial products, there are only 4 products whose average RCA calculation is greater than 1 . These products include automotive products, namely first, HS 8702 Motor vehicles for transport with passengers greater than or equal to 10 persons.

The average RCA for this product in RCEP is 1.53 in the world 0.38 and in ASEAN is 1.25. RCEP countries that import a lot of automotive products from Indonesia are ASEAN countries. Second, products with HS 8707, namely Bodies, including cabs, for tractors, motor vehicles, this product has an average RCA yield for RCEP of 1.23, for the world 0.16 and in ASEAN countries of 0.59. The importing countries for this product are Australia and China. Third, products with HS 8708, namely parts and accessories for tractors, motor vehicles, this product has an average RCA yield for RCEP member countries of 1.16 in the world and 0.56 for ASEAN countries. The importing countries for this product include Japan, China and parts of Australia, including ASEAN countries. Fourth, products with HS 8711, namely motorcycles, including mopeds, and cycles fitted, this product has a very high RCA for RCEP countries, namely 7.59, for the world 3.97 and for ASEAN countries at 7.49. Meanwhile, the countries importing this product from Indonesia are South Korea, Japan, China, Australia and New Zealand. By looking at the following table, it turns out that heavy equipment products in the form of automotive have been able to enter the RCEP market, but non-automotive products still need an increase in competitiveness to enter the RCEP market.

Table 4: Heavy Industrial Products

\begin{tabular}{|c|c|c|c|c|c|c|c|c|c|c|c|c|}
\hline \multirow{2}{*}{ Uraian } & \multicolumn{2}{|c|}{2015} & \multicolumn{2}{|c|}{2016} & \multicolumn{2}{|c|}{2017} & \multicolumn{2}{|c|}{2018} & \multicolumn{2}{|c|}{2019} & \multicolumn{2}{|c|}{ Average } \\
\hline & $R$ & W & $R$ & w & R & $w$ & $\mathrm{R}$ & W & $R$ & W & $R$ & w \\
\hline [8601] Rail locomotives powered from an external source of & 0.00 & 0.00 & 0.00 & 0,00 & 0.00 & 0.00 & 0.00 & 0.00 & 0.00 & 0.00 & 0.00 & 0.00 \\
\hline [8603] Self-propelled railway or tramway coaches, vans and & 0.00 & 0.00 & 0.00 & 0.00 & 0.00 & 0.00 & 0.00 & 0.00 & 0.66 & 0.18 & 0.13 & 0.04 \\
\hline [8606] Railway or tramway goods vans and wagons (excludir & 0.06 & 0.02 & 0.06 & 0.01 & 0.00 & 0.00 & 0.00 & 0.00 & 0.03 & 0.00 & 0.03 & 0.01 \\
\hline [8607] Parts of railway or tramway locomotives or rolling sto & 0.01 & 0.10 & 0.02 & 0.13 & 0.01 & 0.10 & 0.02 & 0.14 & 0.02 & 0.21 & 0.01 & 0.14 \\
\hline [8609] Containers, incl. containers for the transport of fluids] & 0.18 & 0.11 & 0.11 & 0.09 & 0.66 & 0.29 & 0.06 & 0.05 & 0.11 & 0.08 & 0.22 & 0.13 \\
\hline [8701] Tractors (other than tractors of heading 8709 ) & 0.06 & 0.08 & 0.17 & 0.16 & 0.29 & 0.17 & 0.22 & 0.13 & 0.13 & 0.18 & 0.17 & 0.14 \\
\hline [8702] Motor vehicles for the transport of $>=10$ persons, inc & 1.96 & 0.47 & 1.40 & 0.37 & 1.84 & 0.49 & 1.97 & 0.44 & 0.49 & 0.12 & 1.53 & 0.38 \\
\hline [8703] Motor cars and other motor vehicles principally desi & 0.49 & 0.39 & 0.83 & 0.40 & 0.89 & 0.43 & 0.91 & 0.46 & 1.25 & 0.58 & 0.87 & 0.45 \\
\hline [8704] Motor vehicles for the transport of goods, incl. chassi & 0.40 & 0.15 & 0.34 & 0.11 & 0.23 & 0.07 & 0.28 & 0.08 & 0.28 & 0.08 & 0.31 & 0.10 \\
\hline [8705] Special purpose motor vehicles (other than those pri & 0.14 & 0.05 & 0.08 & 0.04 & 0.08 & 0.08 & 0.12 & 0.05 & 0.08 & 0.04 & 0.10 & 0.05 \\
\hline [8706] Chassis fitted with engines, for tractors, motor vehic! & 0.01 & 0.00 & 0.00 & 0.00 & 0.02 & 0.01 & 0.02 & 0.01 & 0.02 & 0.01 & 0.01 & 0.01 \\
\hline [8707] Bodies, incl. cabs, for tractors, motor vehicles for the & 0.07 & 0.04 & 1.35 & 0.19 & 2.37 & 0.29 & 1.42 & 0.12 & 0.95 & 0.13 & 1.23 & 0.16 \\
\hline [8708] Parts and accessories for tractors, motor vehicles for & 1.23 & 0.58 & 1.21 & 0.61 & 1.12 & 0.56 & 1.13 & 0.56 & 1.10 & 0.49 & 1.16 & 0.56 \\
\hline [8709] Works trucks, self-propelled, not fitted with lifting or & 0.42 & 0.20 & 0.99 & 0.33 & 1.28 & 0.40 & 0.23 & 0.10 & 0.25 & 0.13 & 0.64 & 0.23 \\
\hline [8710] Tanks and other armoured fighting vehicles, motorise & 0.00 & 0.01 & 0.00 & 0.09 & 0.07 & 0.04 & 0.00 & 0.10 & 0.01 & 0.01 & 0.02 & 0.05 \\
\hline [8711] Motorcycles, incl. mopeds, and cycles fitted with an a & 3.99 & 2.44 & 4.90 & 2.73 & 6.62 & 3.58 & 9.89 & 4.78 & 12.5 & 6.30 & 7.59 & 3.97 \\
\hline & & & & 1000 & 000 & 10,00 & 0.00 & 0.001 & 0.00 & 0.01 & 0.00 & 0.00 \\
\hline
\end{tabular}

Strategy for Strengthening the Competitiveness of Product Loser Sector RCEP Forum: Strengthening and strategies to increase the competitiveness of loser sector products to enter the market for the RCEP cooperation forum is closely related to government plans and actions. Strategies for strengthening the competitiveness of each loser sector product include the following:

- Continue to identify market access in RCEP partner countries periodically.

The government should continue to periodically identify market access and provide information on new market access for RCEP partner countries to domestic industries. In addition, it continues to provide various facilities and facilities to enter partner country markets. Another thing is to optimize 
the duties and functions of the economic attaché representatives of the Government of Indonesia in RCEP partner countries to carry out an intelligent economy, especially product information and market access in RCEP member countries. Thus, the acquisition of data and information can become a picture of the demand for and access of the relevant domestic market.

- Conducting export dissemination and assistance to industrial player's / product loser sector businesses

This activity is carried out to provide information to domestic industry players, especially the loser sector, to choose various FTA schemes offered from the results of the RCEP agreement, especially those that can provide market access to increase the export of their products. Including, it is necessary to understand the Product Specific Rules and other FTA provisions to take full advantage of the FTA and realize it. Such as the problem of applying tariffs and non-tariffs (NTMs), among others, anti-dumping (ADP), countervailing (CV), quantitative restrictions (QR), safeguards (SG), sanitary and phytosanitary (SPS), special safeguards (SSG), technical barriers to trade (TBT), tariffrate quotas (TRQ), and export subsidies (ES).

- Encouraging increased competitiveness of the product/industry loser sector The form and action of increasing competitiveness are by encouraging continuous improvement in the quality and specialization of products and encouraging the use and availability of domestic raw materials, including the provision of fiscal incentives. Therefore, it requires product standardization which is a requirement that must be carried out by domestic industries.

- Conduct periodic intensive coordination with stakeholders

Encouraging the active role of domestic industry players to file a Trade Remedies petition if there is an indication of unfair trade and a surge in imports that causes the potential for serious injury. Various business associations and forums need guidance and coordination.

- Carry out repairs or reforms of the bureaucracy to get smart regulation.

The need for cooperation between the Government and stakeholders related to the formulation of regulations, policies and business systems, especially the loser sector products. This is useful for producing smart regulations so that an influx of imports can be anticipated, especially as a result of the escape of imported products due to the pretext of Non-Tariff Measures (NTMs) from partner countries.

- The need for regulatory harmonization

Policy Adjustment is one step to anticipate the impact of RCEP implementation. Relevant institutions such as Ministries and Agencies always harmonize existing regulations, including immediately evaluating regulations if they are not effective in their implementation to encourage the competitiveness of loser sector products.

\section{Conclusion and Recommendations}

The results of the above discussion conclude that the average RCA in the 2015-2019 period for the food and beverage product sector mostly has high competitiveness in the RCEP market. Meanwhile, the average RCA for livestock products, light industrial products and heavy industrial products has low competitiveness. However, there are several product items (HS 4 digits) that have relatively strong competitiveness in the RCEP market such as tea, coffee and snack products. For livestock products such as live pig, fish, lobster, shrimp, tuna, squid and others. Light industrial products were handicraft items covered in silver and gold. Meanwhile, heavy industrial products such as automotive industry products are motorized vehicles. Most of the four product sectors still have an average RCA below 1, which means that their competitiveness is still relatively low. Therefore, these products still need to be strengthened in competitiveness to enter the market for RCEP members.

To increase the competitiveness of the four loser sector products to the markets of the RCEP forum partner countries, a strengthening strategy is needed. The strategic steps to strengthen competitiveness include increasing exports through coordination of the Government and business actors, mentoring and identifying market access in RCEP partner countries periodically. In addition, the role of Indonesian government representative institutions in partner countries continues to be optimized as economic intelligence. Another 
thing is to continue to improve the quality and specialization of products and encourage the use of domestic raw materials through several fiscal incentive facilities. Likewise, it continues to improve business efficiency through the provision of various facilities and a conducive business climate by continuing to carry out bureaucratic reforms and harmonization of regulations so that smart regulations will be created.

\section{References}

ADB. (2020). Asian Development Outlook 2020. What Drives Innovation in Asia? Special Topic: The Impact of the Corona Virus Outbreak, an Update. April 2020

Antara, M. (2009). Dampak Pengeluaran Pemerintah dan Wisatawan Serta Investasi Swasta Terhadap Kinerja Perekonomian Bali: Suatu Simulasi Model Accounting Matrix.

Bappenas. (2012). Ekspor Ternak dan Hasil Ternak Melonjak. Perpustakan Bappenas. Diunduh tanggal 22 Agustus 2020 jam 21.32 WIB, dari http://perpustakaan.bappenas.go.id/lontar/file? file=digital/blob/F5151/Ekspor\%20Ternak\%20dan\%20Hasil\%20Ternak\%20Melonjak.htm

Bappenas. (2010). Bab 18. Peningkatan Daya Saing Infrastruktur. Diunduh tanggal 10 September 2020 jam15.23 WIB. Dari https://www.bappenas.go.id/files/1813/5763/0712/bab-18-peningkatan-dayasaing-industri-manufaktur.pdf

Bisnis Indonesia. (2018). Belanda Jadi Pintu Masuk Ekspor Produk Manufaktur, 16 Mei 2018. Diunduh tanggal $30 \quad$ Januari $2019 \quad$ jam $\quad 08: 20$ https://ekonomi.bisnis.com/read/20180516/257/796035/belanda-jadi-pintu-masuk-eksporproduk-manufaktur

Bisnis, Tempo. (2020). Wabah Corona, Sri Mulyani Sebut 8 Industri Ini Berpotensi Cuan, 10 Agustus 2020. Diunduh tanggal 10 Agustus 2020 jam 08.33 dari https://bisnis.tempo.co/read/1328566/wabahcorona-sri-mulyani-sebut-8-industri-ini-berpotensi-cuan

Ceic data, com. (2020). Population of Singapore 1950-2020.

Dahar, D. \& Oktaviani, R. (2014). Analisis Pemberlakuan Non Tariff Measures (NTM) Pada Ekspor Hortikultura Indonesia ke Asean +3. Jurnal Bina Ekonomi, 18(1), 98-116.

Erkan, B. \& Sarıçoban, K. (2014). Comparative Analysis of the Competitiveness in the Export of Science-Based Goods Regarding Turkey and the EU+13 Countries. International Journal of Business and Social Science, 5(8/1), 117-130.

Fukunaga, Y. \& Isono, I. (2013). Taking ASEAN+1 FTAs towards the RCEP: A Mapping Study1.Eria Discussion Paper series. Economic Research Institute for ASEAN and East Asia. ERIA-DP-2013-02. January 2013, 1-37.

Gao, H. \& Shaffer, G. C. (2019). The RCEP: Great Power Competition and Cooperation over Trade. Journal of International Economic Law, Forthcoming UC Irvine School of Law Research Paper Series No. 202109. School of Law. University of California.

Harits, A. \& Nu'man. (2005). Kebijakan Pengembangan Industri Kecil dan Menengah Sebagai Upaya Untuk Menghadapi Era Perdagangan Bebas (Suatu Model Konseptual Dalam Pengembangan IKM). Jurnal Mimbar, XXI, 3.

ILO (International Labour Office) and ILO Office for Indonesia. (2013). The Impact of Trade Liberalization on Bilateral Relations between Indonesia and Three Countries (China, India, and Australia) on ExportImport Performance, National Output and Job Opportunities in Indonesia: Simulation Analysis of Social Accounting Matrix (SAM) and the SMART Model

Media Indonesia. (2020). Peringkat Daya Saing Indonesia. Diunduh tanggal 20 Agustus 2020 jam 07.34 WIB dari https://mediaindonesia.com/read/detail/328988-peringkat-daya-saing-indonesia-turun-keposisi-40

Ministry of Industry. (2019). Ministry of Industry Policy Post-Completion of the RCEP Agreement. Directorate of International Industrial Access, Ministry of Industry. December 2019. Jakarta

Moenardy, D. F. (2020) Indonesia's Strategy in Facing the Regional Comprehensive Economic Partnership (RCEP). Palarch's of Journal of Archaeology of Egyp/Egyptology, 17(10), 1164-1177.

Obradovic, L. (2016). The role of bilateral and regional trade agreements in the modernization of taxation and revenue policy in developing economies. World Customs Journal, 6(2), 73-92. 
Mutiara, U., Hasibuan, R. R., \& CandanniL. R. (2020). Indonesia Perspective Related to Investor-Dispute Mechanism Draft Agreement of Regional Comprehensive Economic Partnership. International Journal of Global Community, 3(1), 9-36.

Ragimun \& Sri, W. (2019). Strategy of Strengthening Food and Beverage Industry in Indonesia. Journal of Economics and Behavioral Studies, 11(4), 102-110

Rahman, M. M., Marikan, D. A. A., Bakar, N. A. A. \& Arip, M. A. (2017). Sectoral GDP Convergence of Selected RCEP Countries: Lead or Lags? International Journal of Business and Society, 18(2), 669-676.

Sinaga, M. \& Bonar. (2007). Keterkaitan Sektor Ekonomi dan Distribusi Pendapatan di Jawa: menggunakan pendekatan Social Accounting Matrix.

Siudek, T. \& Aldona, Z. (2014). Competitiveness in the Economic Concepts, Theories and Empirical Research. Oeconomia, 13(1), 91-108.

Tangenjaya, B. (2014). Daya Saing Produk Peternakan: Ceruk Pasar. Balitbang. Kementan. Jakarta

Tambunan, T. (2010). Perdagangan Internasional dan Neraca Pembayaran, Teori dan temuan Empiris, LP3ES, Jakarta

Ulfah, M. \& Felianty, T. A. (2017). Analysis of Competitiveness and the Impact Prediction of Indonesia's Participation in Regional Comprehensive Economic Partnership (RCEP). Asia Pacific Business and Economics. Conference.ui.ac.id

Yose, R. \& Damuri. (2020). Greater Cooperation on Covid -19: Between Aspiration and Reality. Centre for Strategic and International Strategies.

Xiao, Y. (2015). Competitive Mega-Regional Trade Agreements: Regional Comprehensive Economic Partnership (RCEP) vs. Trans-Pacific Partnership (TPP). College Undergraduate Research Electronic Journal (CUREJ). University of Pennsylvania, 12-24. 